\title{
PREPERENSI KONSUMEN DALAM PEMBELIAN SAYURAN PENELITIAN DI WILAYAH (BKPP) CIREBON
}

\author{
Iqbal Arraniri* \\ Universitas Kuningan \\ iqbal@uniku.ac.id \\ Yoyo Sunaryo $\mathbf{N} * *$ \\ Universitas Swadaya Gunung Jati \\ sunaryon@yahoo.co.id
}

\begin{abstract}
ABSTRAK
Kebutuhan kecukupan gizi masyarakat, dapat dilihat dari besarnya jumlah konsumsi sayuran per hari. Sumber vitamin dan mineral serta unsur mikro, pembentuk tubuh tersedia dalam produk sayuran. Penelitian ini bertujuan untuk mengetahui preperensi konsumen pembelian sayuran, dan faktor-faktor yang mempengaruhi keputusan konsumen dalam pembelian sayuran. Di satu sisi para pelaku usahatani sayuran menanam komoditas yang dibutuhkan masyarakat, dijual atas permintaan pasar. Di sisi lain sebagai informasi bagi para produsen sayuran untuk menghindari terjadinya keruahan produksi, supley yang berlebihan dan mengurangi terjadinya resiko harga pasar yang rendah.

Penelitian dilaksanakan Wilayah Kerja Badan Koordinasi Penyelengaraan Pembangunan (BKPP) Cirebon, meliputi Kabupaten dan Kota Cirebon, Kabupaten Indramayu, Kabupaten Majalengka dan Kabupaten Kuningan, Provinsi Jawa Barat. Metoda penelitian survey, dengan teknik analisis deskriptif kualitatif. Penentuan sampel daerah berdasarkan stratifaid random sampling, yaitu menetapkan keterwakilan wilayah dengan kataristik masyarakat yang berbeda. Masyarakat yang bermukim di kawasan pegunungan ditetapkan di Kuningan dan masyarakat yang bermukim di kawasan pantai ditetapkan Kota Cirebon. Teknik penetapan sampel non peluang dengan metode accidental sampling (teknik pengambilan sampel berdasarkan kebetulan). Objek penelitian adalah konsumen yang sedang membeli atau telah membeli sayuran di Pasar Kepuh Kuningan dan di Pasar Jagasatru Cirebon.

Hasil penelitian menunjukkan bahwa : Faktor lingkungan berpengaruh terhadap pembelian sauran di Kota Kuningan katagori tinggi dengan factor loading 0,80 dan di Kota Cirebon katagori sedang $(0,70)$. Faktor psikologist yang berpengaruh terhadap pembelian sayuran di Kota Kuningan dan di Kota Cirebon sama-sama dalam kategori sedang dengan factor loading $(0,70)$. Faktor atribut yang berpengaruh terhadap pembelian sayuran di Kota Kuningan katagori sedang dengan factor loading 0,73 dan di Kota Cirebon katagori tinggi dengan factor loading $(0,81)$
\end{abstract}

Kata Kunci : Perilaku Konsumen, Sayuran, Analisis faktor.

\section{PENDAHULUAN}

\section{Latar Belakang}

Masyarakat di Wilayah Kerja Koordinator Penyelenggaraan Pembangunan (BKPP) Cirebon, Jawa Barat Umumnya memiliki dua karakteristik masyarakat, yaitu masyarakat yang bermukim di pinggian pantai dan masyarakat yang bermukin di pinggiran hutan. Masyarakat pantai yaitu Kabupaten/Kota Cirebon dan Kabupaten Indramayu, masyarakat pegunungan yaitu Kabupaten Majalengka dan Kabupaten Kuningan. Kedua komunitas masyarakat tersebut, memiliki ke khasan masyarakat Jawa Barat yaitu pemakan sayuran yang cukup tinggi. Kebiasaan makan sayuran, biasa 
makan dengan porsi sayuran dalam bentuk olahan atau sayuran mentah (lalaban) dengan sambal terasi khas yang diolah sendiri.

Disisi lain kesadaran masyarakat tentang makanan bergizi berdampak pada peningkatan terhadap komoditas sayuran baik kuantitas maupun kualitasnya, karena itu harus dikembangkan menjadi komoditas agribisnis dalam rangka memanfaatkan peluang dan keuntungan komparatif [1].

Hasil penelitian terdahulu menunjukan bahwa produk sayuran, sudah tersedia di berbagai tempat berbelanja, di pasar tradisional tanpa kemasan dan di pasar modern dengan berbagai kemasan yang menarik. Daya tarik yang disajikan di pasar modern, menunjukan bahwa posisi berbagai jenis sayuran berada pada level yang semakin baik di mata konsumen. Jenis sayuran yang disajikan, sangat bervariasi dan beraneka ragam sayuran ada sayuran dataran rendah dan sayuran dataran tinggi. Maka pada waktu sayuran di jajakan di pasar tradisional harganya cukup terjangkau terutama untuk segemen masyarakat menengah kebawah, sedangkan di outlet-outlet dengan kemasan yang baik, harganya agak tinggi untuk segmen pasar dengan tingkat pendapatan menegha ke atas.

Karakteristik konsumen yang heterogen baik dari aspek ekonomi, sosial, dan budaya, dapat mempengaruhi perilaku konsumen. Menurut Kotler [2] perilaku konsumen merupakan kegiatankegiatan individu yang secara langsung terlibat dalam hal mendapatkan dan mempergunakan barang dan jasa, termasuk didalamnya proses pengambilan keputusan pada persiapan dan penentuan kegiatan-kegiatan tersebut.

Pemahaman terhadap prepernesi konsumen juga berarti mengetahui siapa dan bagaimana karakteristik serta keinginan konsumen. Faktor-faktor apa yang menjadi pertimbangan konsumen dalam memilih komditas sayuran, hal ini ditentukan oleh latar belakang konsumen. Pada level ekonomi, faktor harga menjadi alat ukur untuk membeli komoditas sayuran. Dari sisi sosial, posisi masyarakat yang terbentuk keran pendidikan, status sosial akan memiliki variasi pembelian sayuran yang lebih banyak dan jenisnya makin luas. Dan ditinjau dari sisi bidaya, masyarakat pantai terbiasa makan sayuran dataran rendah dan masyarakat di pinggiran hutan akan mengkonsumsi sayuran dataran tinggi.

Kebutuhan dan keinginan konsumen dapat dipelajari melalui proses keputusan pembelian, pilihannya bisa jatuh pada jenis sayuran akar, jenis sayuran batang, jenis sayuran daun, jenis sayuran bunga, immanuture fruit dan mature fruit. Sayuran akar termasuk wortel (Daycus carota), lobak (Raphanus sativus), kentang (Solanum tuberosum), bawang bombay (Allium cepa var).

Sayuran batang Asparagus (Asoaragus officinalis), rebung, Kohlrabi (Brassica oleraceae). Sayur Daun termasuk Bayam (Amaranthum viridis), Kangkung (Ipompoea aquatic), kubis (Brassica oleraceae), sawi (brassica juncea), salada (lactusa sativa), Saledri (Apium graveolens), daun bawang (Ligularia ficheri). Sayuran bunga yaitu bunga kol (Brassica oleraceae botrytis), kubis bunga ( Romanesco), kecombrang (Etlingera elator). 
Immature Fruit yaitu baby corn (jemays ), ketimun (Cucumis sativus), kecipir (Psophocarpus tetragonolobus), kapri (Pisum sativum), kacang polong (Pisum sativum), Pare (Momordica charantia), petai (Parcia speciose), buncis (Phaseolus vulgaris), terong (Salanum melongena). Mature fruit yaitu Tomat (Licopercicon) dan jenis lain yeitu jamur dari keluarga ascomycetes dan basidiomycetes.

Berdasarkan ketinggian tempat dapat dibedakan atas a). Sayuran dataran rendah seperti terung, kacang panjang, emes, oyong, timun dan sebagainya b). Sayuran dataran tinggi seperti petsai, ceisin, sawi, lobak, kol dan sebagainya. Sayuran dataran rendah memiliki daya simpan yang lebih lama jika dibandingkan dengan dataran tinggi yang mudah rusak (ferisable) karena pengangkutan dan penyimpanan,

Berdasarkan uraian di atas, penulis tertarik untuk mengetahui preperensi konsumen dan faktor-faktor yang mempengaruhi perilaku konsumen dalam pembelian sayuran di pasar Kepun dan pasar Jagasatru. Konsumennnya sangat beragam karena bersumber dari kulture yang bebebeda, yakni masyarakat konsumen yang berasal dari masyarakat dari WKPP Cirebon meliputi kabupaten/Kota Cirebon, Kabuaten Indramayu, Kabupaten Majalengka dan Kabupaten Kuningan.

\section{METODE PENELITIAN}

Penelitian ini dilakukan di pasar Kepuh Kabupaten Kuningan dan Pasar Jagasatru Kota Cirebon. Pemilihan lokasi dilakukan secara sengaja (purposive) dengan pertimbangan bahwa pasar tersebut merupakan pasar yang berada di pusat Kota Kuningan dan pasar di Kota Cirebon, merupakan salah satu pasar induk sayuran yang dikelola langsung oleh pemda setempat

Responden dalam penelitian ini, ditetapkan dengan menggunakan teknik sampel non peluang [3]. Jadi pengambilnnya dengan metode convenience sampling atau accidental sampling yang merupakan teknik pengambilan sampel berdasarkan kebetulan. Kerana populasinya adalah pembeli sayuran yang sedang bertransaksi membeli sayuran. Sehingga responden adalah mereka yang sudah membeli sayuran atau yang sedang membeli sayuran. Guna memenuhi kebutuhan penelitian, adalah mereka yang bersedia di wawancarai untuk waktu sesaat, jumlahnya ditetapkan 30 responden dari setiap lokasi penelitian sehingga total resonden dari dua pasar dietapkan sebanyak 60 orang.

Menggunakan analisis deskriptif untuk menggambarkan preperensi konsumen berdasarkan umur, tingkat pendidikan, tingkat pendapatan, jenis pekerjaan, gender, dan menggambarkan proses keputusan konsumen dalam pembelian sayuran. Untuk mengetahui faktor - faktor yang mempengaruhi konsumen dalam keputusan pembelian sayuran, dalam bentuk data ordinal dan dianalisis dengan menggunakan analisis faktor. 


\section{HASIL PENELITIAN DAN PEMBAHASAN}

\section{Karakteristik Umum Responden}

Responden yang dijadikan sample adalah mereka yang sedang belanja atau sudah belanja sayuran di Pasar Kepuh Kuningan dan Pasar Jagasatru Kota Cirebon. Responden yang dapat ditemui dan mau di wawancarai pada saat belanja sayuran adalah sebagai berikut :

Tabel 1. Identitas Responden Berdasarkan Jenis Kelamin dan Umur

Di Pasar Kepuh Kuningan dan Pasar Jagasatru Cirebon

\begin{tabular}{|l|l|c|c|c|c|}
\hline \multirow{2}{*}{ No } & Indentitas Responden & \multicolumn{2}{|c|}{ Jenis Kelamin (\%) } & \multicolumn{2}{|c|}{ Umur (\%) } \\
\cline { 3 - 6 } & & Laki-laki & Perempuan & 20 s/d 35 & 35 s/d 50 \\
\hline & Pasar Kepuh & 10 & 90 & 85 & 15 \\
\hline & Pasar Jagasatru & 20 & 80 & 75 & 25 \\
\hline
\end{tabular}

Tabel diatas menunjukan bahwa konsumen yang belanja sayuran di Pasar Kepuh sebanyak 90 $\%$ responden berjenis kelamin perempuan dan $10 \%$ responden berjenis kelamin laki-laki, sedangkan di Jagasatru sebanyak $80 \%$ responden berjenis kelamin perempuan dan $20 \%$ responden berjenis kelamin laki-laki. Pembeli pria di Pasar Kempuh menyatakan, membeli sayuran karena kebetulan ada perlu lain dan pembeli di Pasar Jagastru karena kebutuhan untuk hobi hewan peliharaanya, sedangkan pembeli anak-anak jawabannya sama disuruh ibunya sekalian pulang sekolah. Ditinjau dari usia, konsumen di Pasar Kepuh umumnya antara 20 s/d 35 sebanyak $85 \%$ responden dan $15 \%$ responden ibu-ibu yang sudah berumur antara 35-50 tahun, konsumen di Pasar Jagastru umumnya antara 20 s/d 35 sebanyak $75 \%$ responden dan $25 \%$ responden ibu-ibu yang sudah berumur antara 35-50 tahun. Data hasil analisis disajikan sebagai berikut :

Tabel 2. Identitas Responden Berdasarkan Pendapatan dan Pengaluaran

Di Pasar Kepuh Kuningan dan Pasar Jagasatru Cirebon

\begin{tabular}{|l|l|c|c|c|c|}
\hline \multirow{2}{*}{ No } & Indentitas & \multicolumn{4}{|c|}{ Ekonomi Responden (\%) } \\
\cline { 3 - 6 } & Responden & $\begin{array}{c}> \\
1.000 .000\end{array}$ & 1.000 .000 & 2.000 .000 & $>2000.000$ \\
\hline & Pasar Kepuh & 20 & 45 & 25 & 10 \\
\hline & Pasar Jagasatru & 5 & 25 & 45 & 25 \\
\hline
\end{tabular}

Tabel diatas menunjukan bahwa stratifikasi ekonomi masyarakat di Cirebon dan Indramayu lebih baik dari pada di Kuningan dan Majalengka. Namun ada kesamaan, bahwa sebaran pendapatan responden berakumulasi pada kisaran tingkat pendapatan antara Rp. $1.000 .000-2.000 .000$ sebanyak $70 \%$ responden. Pengeluaran per kapita/ bulan untuk membeli sayuran Rp. $100.000-200.000$ 
sebanyak 85\% responden, pengeluaran kurang dari Rp. 100.000 sebanyak 2,5\% responden, dan pengeluaran lebih dari Rp. 200.000 sebanyak 7,5\% responden. Dengan pengeluaran per bulan tertinggi Rp. 250.000, pengeluaran terendah Rp. 72.000, dan rata - rata pengeluaran per bulan untuk membeli sayuran Rp. 153.550.

\section{Proses Keputusan Pembelian Sayuran}

Preperensi responden dalam membeli sayuran karena mengetahui kandungan vitamin yang terdapat dalam sayuran, dinyatakan sangat tergantung dari tingkat kognitif seseorang dan tingkat aksebititas responden. Data hasil analisis disajikan sebagai berikut :

Tabel 1. Preperensi Responden terhadap Keputusan Pembalian Sayuran Di Pasar Kepuh Kuningan dan Pasar Jagasatru Cirebon

\begin{tabular}{|l|l|c|c|c|c|}
\hline \multirow{2}{*}{ No } & Indentitas & \multicolumn{2}{|c|}{ Nilai Gizi (\%) } & \multicolumn{2}{c|}{ Infromasi (\%) } \\
\cline { 3 - 6 } & Responden & $\begin{array}{l}\text { Kandungan } \\
\text { Gizi }\end{array}$ & Kebisaaan & Teman & $\begin{array}{r}\text { Media } \\
\text { Sosial }\end{array}$ \\
\hline & Pasar Kepuh & 66 & 34 & 68 & 32 \\
\hline & Pasar Jagasatru & 85 & 15 & 48 & 52 \\
\hline
\end{tabular}

Tabel diatas menunjukan bahwa responden di Kuningan dan Majalengka menyatakan membeli sayuran karena kandungan gizi dinyatakan oleh $66 \%$ dan karena kebiasaan dinyatakan sebanyak $34 \%$ responden. Responden di Cirebon dan Indramayu pengatahuan tentang kandungan gizi pada sayuran lebih tinggi dimana responden menyatakan membeli sayuran karena kandungan gizi dinyatakan oleh $85 \%$ dan karena kebiasaan dinyatakan sebanyak $15 \%$ responden. Sumber informasi responden di Kuningan dan Majalengka tentang sayuran yang diperoleh dari teman/kerabat/tetangga/saudara sebanyak $68 \%$ responden dan $32 \%$ memperoleh infirmasi dari media sosial. Sumber informasi responden di Cirebon dan Indramayu tentang sayuran yang diperoleh dari teman/kerabat/tetangga/saudara sebanyak $48 \%$ responden dan $32 \%$ memperoleh infirmasi mencari dari media sosial.

Pemilihan lokasi di pasar Kepuh dan Pasar Jagasatru dengan nilai rata-rata karena pertimbangan harga sebanyak 24 orang $(60 \%)$, dengan pertimbangan pelanggan sebanyak $65 \%$ responden, dengan pertimbangan banyak varian sayuran sebanyak 72,5\% responden dengan pertimbangan manajemen pasar sebanyak $45 \%$ responden. Tanggapan responden pasca pembelain sayuran di Pasar Kepuh dan Pasar Jagasatru puas, ditinjau dari berbagai aspek harga, jenis, tempat, kemudahan mapun manajemen pasar. Kondisi ini, didukung oleh kebijakan kedua kota dalam membangun pasar tradisional yang bersih dan indah. Hala ini sangat menarik peminat sahyuran, kembali belanja di pasar tradisional. 


\section{Analisis Faktor - Faktor yang Mempengaruhi Keputusan Pembelian}

Nilai rata-rata dari dua lokasi penelitian, dengan menggunakan variabel faktor proses pengambilan keputusan pembelian sayuran, dikelompokan menjadi 3 faktor. yang pengaruh nyata terhadap keputusan pembelian sayuran dengan nilai faktor loading antara 0,47-0,92.

1) Faktor lingkungan yaitu : a). Pengaruh budaya di Kuningan dan Majalengka katagori tinggi dengan factor loading 0,80 dan di Cirebon dan Indramayu katagori sedang (0,70), b). Pengaruh motivasi keluarga di Kuningan, Majalengka, Cirebon dan Indramayu sama-sama dalam kategori sedang dengan factor loading $(0,63)$, c). pengaruh kelas sosial di Kuningan dan Majalengka katagori rendah dengan factor loading 0,47 dan di Cirebon dan Indrmayu katagori sedang $(0,73)$.

2) Faktor psikologist yaitu : a). Pengaruh pengolahan informasi di Kuningan, Majelengka, Cirebon dan Indramayu sama-sama dalam kategori sedang dengan factor loading $(0,70)$, b). Pengaruh harga sayuran di Kuningan dan Majalengka katagori tinggi dengan factor loading 0,83 dan di Cirebon dan Indramayu katagori tinggi factor loading $(0,81)$, c). Pengaruh jenis sayuran di Kuningan dan Majalengka katagori tinggi dengan factor loading 0,80 dan di Cirebon dan Indramayu katagori sedang (0,75), d) Kelas sosial di Kuningan dan Majalengka kategori sedang dengan factor loading $(0,70)$ dan di Cirebon dan Indamayu sama dalam tinggi factor loading $(0,81)$.

3) Faktor atribut yaitu : a). Pengaruh harga di Kuningan dan Majalengka katagori tinggi dengan factor loading 0,83 dan di Cirebon dan Indramayu katagori tinggi factor loading $(0,81) \mathrm{b})$. Pengaruh kualitas di Kuningan dan Majalengka katagori sedang dengan factor loading 0,73 dan di Cirebon dan Indramayu katagori tinggi factor loading $(0,81)$. Hal ini sejalan dengan hasil penelitian Hamidi [4] bahwa keputusan pembelian konsumen dipengaruhi secara signifikan oleh kualitas produk. c). Jenis sayuran di Kuningan dan Majalengka katagori tinggi dengan factor loading 0,83 dan di Cirebon dan Indramayu katagori sedang factor loading $(0,72) \mathrm{d})$. Pengaruh lokasi di Kuningan, Majalengka, Cirebon dan Indramayu sama dengan katagori sedang dengan factor loading 0,73 .

Kabiasaan makan dan budaya makan di kedua daerah dengan kulture berbeda memiliki sisi perbedaan, hal ini akan berpengaruh terhadap preperensi pembalian sayuran: masyarakat Kota Kuningan yang dipengaruhi oleh budaya sunda, biasa memakan sayuran dalam bentuk lalaban dan masakan berkuah. Sedangkan masyarakat Kota Cirebon, kebiasaan makan sayuran dengan masakan berkuah. Makan sayuran lalaban, biasanya menggunakan jenis sayuran daun dan sedikit sayuran buah (timun dan terung). Jenis makanan berkuah seperti lodeh, sayur asem, sop, tumis, capcai, pecel biasanya menggunakan jenis sayuran berdaun. Porsi yang sama menggunakan sayuran daun, buah 
dan umbi yaitu makanan sayuran dalam bentuk urab, pecel dan tumis. Jenis masakan ini, sama-sama di sukai oleh masyarakat kota Kuningan maupun masyarakat kota Cirebon.

\section{KESIMPULAN}

Preperensi masyarakat Kuningan dan Majalengka, masyarakat Cirebon dan Indramayu, memiliki nilai-nilai tersendiri dalam memilih jenis sayuran yang di konsumsi keluarga, atas dasar kulture masing-masing dimana hasil penelitian di simpulkan sebagai berikur :

1. Faktor lingkungan berpengaruh terhadap pembelian sauran di Kuningan dan Majalengka katagori tinggi dengan factor loading 0,80 dan di Cirebon dan Indramayu katagori sedang $(0,70)$,

2. Faktor psikologist yang berpengaruh terhadap pembelian sayuran di Kuningan, Majalengka, Cirebon dan Indramayu sama-sama dalam kategori sedang dengan factor loading $(0,70)$,

3. Faktor atribut yang berpengaruh terhadap pembelian sayuran di Kuningan dan Majalengka katagori sedang dengan factor loading 0,73 dan di Cirebon dan Indrasmayu katagori tinggi dengan factor loading $(0,81)$.

\section{DAFTARA PUSTAKA}

[1] B. Irawan, "Membangun Agribisnis Hortikultura Terintegrasi dengan Basis Kawasan Pasar," Forum Penelit. Agro Ekon., vol. 21, no. 1, p. 67, 2016.

[2] P. Kotler, G. Armstrong, S. H. Ang, S. M. Leong, C. T. Tan, and O. Yau, Principles of marketing: A global perspective. Prentice-Hall, 2009.

[3] Sugiyono, "Methode Untuk Penelitian," Alph. Bandung, 2005.

[4] D. Z. Hamidi and S. Prakoso, "Pengaruh Kualitas Produk terhadap Keputusan Pembelian Konsumen Melalui Variabel Intervening Kepuasan Konsumen," Ekonomak, vol. 4, no. 2, pp. $1-18,2018$. 